\title{
Will Corporate Train on Ethics and Moral?
}

\author{
${ }^{1}$ Prof. Anant Deogaonkar, ${ }^{2}$ Mr. Ashish Deogaonkar, ${ }^{3}$ Ms. Sampada Nanoty \\ ${ }^{1}$ Department of Management Technology, Shri Ramdeobaba College of Engineering and Management, \\ ${ }^{2}$ Head, Sales \& Marketing, 3M India Ltd. \\ ${ }^{3}$ M.S.University, Vadodara \\ Email:deogaonkara1@rknec.edu,daashish@mmm.com,sampadananoty@gmail.com
}

Received: $20^{\text {th }}$ September 2018, Accepted: $11^{\text {th }}$ October 2018, Published: $31^{\text {st }}$ October 2018

\begin{abstract}
Will the corporate will to train on ethics and moral? The answer is the sole purpose of the article, ardently emphasizing on the strong need for training to enhance moral and ethical competencies in employees working in corporates. Contemporary era least expects employees to inherit moral and ethical values naturally unlike the people of past times. Profound association of employees with their work makes the training on ethics and morals legit imperative. This will inculcate the culture of pristine proficiencies in the performance standards of the employees. Several theories have been previously published pertaining to various training methods and principles followed by corporates all across, however the intent here is to precisely understand the present scenario of moral and ethical practices in corporates. The focus here is on the need to enhance moral and ethical competencies of corporate employees at each echelon.
\end{abstract}

\section{Keywords \\ Training, Ethics, Moral, Employee, Corporate}

\section{Introduction}

Training programs are more often conceived with the notion of, "Break from the programmed sedentary work setup, for stress release" of the personnel. Comportment trainings are clichés to corporates nowadays, imparting training to each and every employee. The training content is a fixed set pre-programmed and most likely ushered along with prestigious, performance appraisal process. Pondering upon the impact of such trainings, is it really adding up in customizing or ameliorating the behavioral traits of the personnel? Is it contributing to the escalation of the ethical and moral conduct of the corporate employees? And surely to note whether is it up scaling the level of organizational performance excellence? Such questions and a few related ones derive the necessity to investigate and address upon the imperative need of comportment training and the methods devised for imparting. The realization of the ardent need to train, for the adoption of ethical, moral and emotional competencies has derived due to the alarming increase of corporate crimes. The highlights of the global crime scenario majorly spot the moral, ethical and emotional competency issues in the organizations. Here, take a glance over a few brief glimpses of such cases across the globe.

The corporate crime update, September 2017 highlights the latest status in relation to corruption, money laundering, fraud and such matters. An employee in United Kingdom arrested for suspicion of crypto currency fraud. In Germany, Members of Deutsche Boerse's management board will be questioned in an investigation into its chief executive officer Carsten Kengeter. German authorities launched a criminal probe into Kengeter in February over suspicions of insider trading. Kengeter has been accused of making illicit share purchases before work began on a takeover deal. A German cyber security firm has reported that manufacturers have become the top target of cyber criminals. In united States on 7 September 2017, the New York Department of Financial Service ("NYDFS") announced fines against Habib Bank and its New York branch of \$225 million for anti-money laundering ("AML") failures. On 6 September 2017, the Department of Justice ("DOJ") announced charges against several Turkish citizens which include: conspiring to use the US financial system to conduct transactions on behalf of the Government of Iran and other Iranian entities; laundering funds in connection with those illegal transactions; using millions of dollars in bribe payments; and defrauding several financial institutions by concealing the true nature of these transactions. On 29 August 2017, the DOJ announced charges against a retired army colonel for his role in a foreign bribery and money laundering scheme in connection with a planned $\$ 84$ million port development project in Haiti. The retired colonel, Joseph Baptiste has been charged with one count of conspiracy to violate the Foreign Corrupt Practices Act and to launder money.

In Middle East, The Dubai Court of First Instance has heard how a hacker and his cohort posed as an American national in order to transfer $\$ 500,000$ from a personal bank account to a financial services company. Dubai Police have noted how cybercriminals are using this tactic to steal financial and personal details. A purchase officer at Dubai Petroleum has gone on trial for allegedly seeking illegal commissions from suppliers. A consultant, accused of tricking a South African businessman into doing business with him, was acquitted by the Dubai Court of First Instance due to lack of evidence. The Criminal Investigation Department ("CID") in Dubai has announced that two employees of a small money exchange illegally diverted funds that were to be wired into consumer bank accounts into their own. In China, Ex senior executive of China Development Bank sentenced to 14 years of imprisonment. Prosecutors in South Korea have launched an investigation into suspicions of 
accounting fraud at Korea Aerospace Industries Co. Two former employees of Singapore Statutory Boards Employees' Cooperative Thrift and Loan Society ("Co-op"), Arni Ahmad and Hanati Jani, were sentenced to 12 years' imprisonment and 9 years and 8 months' imprisonment respectively for defrauding the Co-op of more than $\$ 5.1$ million. India is drafting its first set of marketing rules for pharmaceutical firms, restricting gifts and trips offered to doctors and pharmacists up to the value of 100 rupees $(\$ 15)$.

The above said corporate issues are just the highlights which are available with social media all across the globe. The fraudulent behavior witnessed in the industry definitely demands for training the employees for the moral, ethical conduct.

\section{Training Moral and Ethics}

The terms moral and ethics though seemingly different, have an interrelation nexus. On one hand moral shows up the right behavior of individuals while ethics portray the right character in a given situation. But both terms are twins to each other. The application of ethical reasoning of a decision maker is the referred characteristic of moral intensity (Harvey, 2007). Some of the basic morals like lending a helping hand, equality sovereignty, etc. are curbed well in terms of good corporate governance practices. Social responsibility manifests itself in the vision of code of ethics. (Stevens, 1994). It is considered that morals are regarded as the underpinning foundation of ethics which can be applied to corporations.

It was only in the late past era where organizations could expect the employees to adapt ethics and morals merely by socialization. The current concurrent world, obligates organizations to devote and spend for the training on ethics and morals to curb personnel to handle ethical dilemmas inherent at workplace.(Herald August2018) Business ethics training must be embraced by all well-meaning business entities whether for-profit or not-for-profit, and must take place at all echelons of the organization. Training in ethics must include directors, managers and employees, corresponding to their differing levels of responsibility.

\section{The Way Ahead}

All corporates across the globe strive hard for benchmarking performance. The performance excellence ultimately establishes a culture of cut throat, resilient competition among the employees which more often illustrates demonstration of compromise over ethics and moral. The issues pertaining to ethics and morals mundane the entire organization and have long term repercussions in not just professional but even the personal terms amidst the employees . The cut throat competition perhaps is the one of the principal reason from the variety of reasons for non-ethical conduct by the employee. The media targets delinquencies by businesses and executives as humongous scandals. Such scandals result into mainstream bungle, such as losing customer's faith on the business house. This pulls back the organization with tremendous quake. Organizations need to be more specific and precise on training the adoption of ethics and morals to the employees and ought to develop a way to create highest of the ethical and moral conduct illustrated by all. Though, a lot of business houses have demonstrations of training practices in place but the measurement of its effectiveness to the displayed demonstration of the ethical and moral conduct by the employees will fetch it it's real worth. A lot of factors about the personal attributes of the employees, the upbringing, the sociocultural aspects also hold a strong impact on the belief system and the psychology of the personnel that imperatives the requirement of instilling the value system of ethics and moral in them. Moreover organizations need to develop the mechanism of assessing the ethical and moral standards of the candidate right from recruitment level. In addition to that the orientation for boosting the morals and ethics should be an extremely mandatory part of the organizational practices. This generates a great demand for the role of a psychologist from the Human Resource Management Team.

\section{Conclusion}

Will the corporate will to train on ethics and moral? Yes, the very manifestation of the excellence in performance standards, conquering pinnacle, establishing benchmarks, necessarily ought to be linked to the pinnacle of ethical and moral work practices demonstrated by the employee. Training on moral and ethics is an ardent and imperative need of the corporates to establish, foster and augment ethical work culture in the organization. The corporate crime rate needs to be seriously studied precisely and understood keenly as a cautionary siren for all the organizations. The corporates can't really afford to ignore the need for adapting ethical conduct and hence the training entailing as well.

\section{References}

1] Anonymous B. 2000. Email from $<$ [name omitted]@hotmail.com>, Subject: Qualitatives Program and Registration, Date sent: Tue, 22 Feb. 2000 13:15:21 PST.

2] Anonymous C. 2000. "Detailed Description of an Application to the Social Sciences and Humanities Research Council of Canada." 6pp.

3] Anonymous D. 2000. Conversation with a Colleague in Gerontology. January.

4] Anonymous E. 2000. Email from < [name omitted@unbsj.ca $>$ to $<$ will@unb.ca>, Subject: notes rein formed consent, Date sent: Sun, 16 Apr 2000 12:09:45 -0300.

5] Anonymous F. 1995. Personal Communication to W.C. van den Hoonaard. Becker, Howard S. 1963. 6] Outsiders: Studies in the Sociology of Deviance. New York. Free Press. Charbonneau, Robert. 1984. "Ethics in Human Research." The IDRC 
Reports. 13 (1): 20-21.

7] Chahal, Kusminder. 2000. "'What will you do with this information?': Ethical Issues and Sensitive Research." Unpubl.Clews, Rosemary. 1999. "Doing Qualitative Research for a PhD: A Case Study of Resolving Challenges." Paper Presented at the 16th Qualitative Analysis Conference, Fredericton, New Brunswick, 13-16 May.

8] Cohen, Stanley. 1972. Fold Devils and Moral Panics. New York. St. Martin's Press. Comarow, Murray. 1993. "Are Sociologists Above the Law?" The Chronicle of Higher Education. 15 Dec.: A44.

9] Curtis, Jenefer. 1999. "The Business of Ethics." Globe and Mail. Satuyrday, 21 August: D1, D4).

Getty, Grace. 1999. Email from <getty@unb.ca> to <will@unb.ca>, Subject, Personal Ltr to qualitative researchers at UNB and STU, Date Sent: Wed, 24 Nov 1999 13:60:44 -0400.

10] Goode, Erich, and Nachman Ben-Yehuda. 1994. Moral Panics: The Social Construction of Deviance. Cambridge U.P.: Blackwell. Graduate Studies and Research. 1979.

11] "University Policy on Research and Other Studies Involving Human Subjects." 4pp. Rev. ["1979 Document"] GVU Center's WWW User Surveys. 2000. URL: http://www.cc.gatech.edu/gvu/user_surveys/Hancock, Karen. 1999. "London's Sex Trade Industry: The Politics of the 'Problem."' Paper Presented at the 16th Qualitative Analysis Conference, Fredericton, New Brunswick, 13-16 May.

12] Jones, Paul. 1998. "Consultation Underway at Simon Fraser Following Coroner's Inquest." CAUT Bulletin. (24 Oct.): 24. Kellner, Florence. 2000. "Yet Another Current Crisis: The Ethics of Conduct and Representation in Fieldwork-Dependent Social Science." Paper Presented at the 17th Qualitative Analysis Conference, Fredericton, New Brunswick, 18-21 May.

13] Levine, Felice J. 1995. "Consent for Research on Children." The Chronicle of Higher Education. (November 10): 8182. Liebow, Eliot. 1993.

14] Tell Them Whom I Am: The Lives of Homeless Women. Toronto: Macmillan Canada. Lowman, John, and Ted Palys. 1998. "When Research Ethic and the Law Conflict." CAUT Bulletin. (June): 6-7.

15] MacDonald, Heather. 1999. Email from < keith@worrall17.freeserve.co.uk> to <will@unb. ca>, Subject: Re: Personal Ltr to qualitative researchers at UNB and STU, Date Sent: Wed, 24 Nov 1999 21:33:20 -0000.

16] Mills, Erin. 2000. "Voices in Harmony/Voices in Discord: Researching Biography,

Writing Autobiography." Unpubl.Office of Research. 1999a. "University Policy on Research Involving Humans." 7pp. ["1999 Document"] -----. 1999b. "Requirements for Informed Consent Form.

" 28 Dec. 6pp.

17] O'Neill, Patrick. 2000. "Good Intentions and Awkward Outcomes: Ethical Gatekeeping in Field Research." Paper Presented at the 17th Qualitative Analysis Conference,

18] https://www.herbertsmithfreehills.com/latest-thinking/corporate-crime-update-september-2017 